\title{
Soils of Tropical Dry Forest and with Different Crops Presenting Ascospores of Monosporascus cannonballus
}

\author{
Rui SALES JÚNIOR ${ }^{1 *}$, Rosemberg F. SENHOR ${ }^{2}$, Erika V. MEDEIROS ${ }^{2}$, \\ Andreia M.P. NEGREIROS ${ }^{1}$, Roberto BELTRÁN ${ }^{3}$, Sami J. MICHEREFF ${ }^{2}$ \\ ${ }^{1}$ Universidade Federal Rural do Semi-Arido, Centro de Ciências Agrárias e Florestais, 59.625-900 Mossoró, Rio Grande do Norte, \\ Brazil;jrrui@hotmail.com (*correspondingauthor);deia_mitsa@hotmail.com \\ ${ }^{2}$ Universidade Federal Rural de Pernambuco, Departamento de Agronomia, 52.171-000, Recife, Pernambuco, \\ Brazil;berg_fit@hotmail.com;.evmbio@gmail.com;smichereff@gmail.com \\ ${ }^{3}$ Universitat Politècnica de València, Departamento de Ecosistemas Agroforestales, 46022 Valencia, España; robelmar@upvnet.upv.es
}

\begin{abstract}
The vine decline caused by Monosporascus cannonballus is a limiting factor in different crops in several countries. The objective of this study was to quantify the $M$. cannonballus ascospores in soils covered with tropical dry forest and areas cultivated with pineapple, cotton, coconut, corn, mango, melon, papaya, sorghum and watermelon. Five areas were sampled in tropical dry forest and every crop. The M. cannonballus ascospores were extracted using the flotation method of sucrose. Ascospores of M. cannonballus were detected in all soil samples from Rio Grande do Norte and Ceará states, including tropical dry forest. There were significant differences among the ascospores densities of $M$. cannonballus, which varied from 0.55 to 2.21 ascospores $\mathrm{g}^{-1}$ soil. The lower densities were found in areas with cotton, coconut, mango, pineapple, and melon within the first and fifth years of cultivation, in addition to uncultivated areas of tropical dry forest. The highest ascospores density was found in papaya areas. Up to date, there is no study to prove that this crop is considered host of this phytopathogen. Cultivated areas with cucurbitaceous with more years of cultivation presented higher densities of $M$. cannonballus ascospores in soils from Brazilian semiarid. However, there is no direct relationship between M. cannonballus population density in the soil and the susceptibility of the host being cultivated in the soil at the time of sampling.
\end{abstract}

Keywords: ascospore extraction; prospecting of soils; root rot; soilborne pathogen; vine decline

\section{Introduction}

Tropical dry areas in Brazil are found in the states of the Northeast region and the north of Minas Gerais, comprising an area of $844,453 \mathrm{~km}^{2}$, equivalent to $11 \%$ of Brazilian territory. The climate of this region, according to the Köppen classification system is BSh, dry semi-arid with low altitude and latitude, average air temperature of $26.7^{\circ} \mathrm{C}$ and relative humidity of $68.9 \%$. The average annual precipitation is around $750 \mathrm{~mm}$, with a rainy period between February and June and low probability of rainfall between August and December. In general, they have shallow, rocky, but fertile soils (Alvares et al., 2014; Alves et al., 2017; Andrade, 2017).

The states of Rio Grande do Norte (RN) and Ceará (CE) located within the tropical dry areas are characterized by a very developed and diversified fruit production activity.
In these states there are two fruit crops that stand out: the cultivation of melon (Cucumis melo L.) presenting an output of 354.8 and 98.5 thousand tons, and watermelon (Citrullus lanatus (Thunb.) Matsum \& Nakai) with 135.3 and 35.5 thousand tons produced, respectively (IBGE, 2016). In Brazil, these crops have a production of 596.4 and 2,090 thousand tons, respectively, exhibiting a value of US \$ 180.2 million (26.5\%) of Brazilian exports of fresh fruits (ANUÁRIO, 2017).

The expansion of these cucurbits, associated with intensive and continuous cultivation, without crop rotation, has increased the incidence and severity of root diseases, which are responsible for the higher losses of productivity and quality of commercialized fruits (Sales Júnior et al., 2007; Senhor et al., 2009). Among the diseases, Monosporascus root rot and vine decline (MRRVD), caused by the fungus Monosporascus cannonballus Pollack \& Uecker, is widely disseminated in the main producing areas 
of Assú-Mossoró (RN) and Baixo Jaguaribe (CE) (Sales Júnior et al., 2004; Andrade et al., 2005; Medeiros et al., 2006; Sales Júnior et al., 2010).

The MRRVD is one of the factors that has also limited the production and expansion of melon, watermelon and other cucurbitaceous crops in the main producing regions of the world for several years. Currently, $M$. cannonballus has been reported causing disease in melon in 22 countries (Cohen et al., 2012; Al-Mawaali et al., 2013; Yan et al., 2016; Markakis et al., 2018).

The major marketed host crops of M. cannonballus are melon and watermelon. However, many plant species support the pathogen growth and are susceptible under artificial or field inoculation conditions (Sales Júnior $e t$ al., 2018). Among them are asparagus (Achyranthes aspera L.), common bean (Phaseolus vulgaris L.) (Mertely et al., 1993; Martyn and Miller, 1996; Cohen et al., 2012), cloverleaf (Trifolium pratense L.), cotton (Gossypium hirsutum L.), cucumber (Cucumis sativus L.), lily (Iris sp.), maize (Zea mays L.), sesame (Sesamum indicum L.), sorghum (Sorghum bicolor (L.) Moench), tomato (Solanum lycopersicum L.) and wheat (Triticum aestivum L.).

Infection in plant roots can occur from fungal mycelium that has survived in weeds (Sales Júnior $e t$ al., 2012), soil, cultural remains or ascospores that germinate when stimulated by root exudates or by soil microbiota (Stanghellini et al., 2000; Stanghellini and Misaghi, 2011; Aleandri et al., 2017). Thus, ascospores of $M$. cannonballus are considered as primary inoculum and are presumed to withstand in the soil for many years in the dormancy stage (Waugh et al., 2003). For this reason, the monitoring of $M$. cannonballus inoculum in soil is a measure that may assist in the management of MRRVD (Mertely et al., 1993; Waugh et al., 2003).

No study to date has shown a selective medium for isolation of this organism in the soil, being the method of physical extraction by flotation of sucrose the most used to quantify ascospores of M. cannonballus in areas of cucurbit production (Mertely et al., 1993; Waugh et al., 2003; Radewald et al., 2004; Stanghellini et al., 2004; Beltrán et al., 2008; Sales Júnior et al., 2006).

Previous studies on areas cultivated with melon have detected the population level of $M$. cannonballus in Texas (USA) of 14.40 ascospores $\mathrm{g}^{-1}$ soil (Mertely et al., 1993), in California (USA) of 2.10 ascospores $\mathrm{g}^{-1}$ soil (Radewald et al., 2004) and in Spain of 2.34 ascospores $\mathrm{g}^{-1}$ soil (Beltrán et al., 2005). In Brazil, Medeiros et al. (2006) studied the population of $M$. cannonballus in fields of melon production as well as areas of the Caatinga in the states of $\mathrm{CE}$ and $\mathrm{RN}$ and found ascospore levels ranging from 0.50 to 26.04 and from 0.18 to 18.30 ascospores $\mathrm{g}^{-1}$ soil. Values higher than 3.0 ascospores $\mathrm{g}^{-1}$ soil were found in 40 and $60 \%$ of the fields of the aforementioned states, respectively.

Considering all the circumstances stated above, the present work aims to quantify ascospores density of $M$. cannonballus in soils of tropical dry forest which were never cultivated and areas cultivated with different crops, in the Brazilian semi-arid region.

\section{Materials and Methods}

\section{Collection of soilsamples}

Soil samples were collected from 60 areas, five of which were non-cultivated pertaining to tropical dry forest, and 55 areas cultivated with different crops, including coconut (Cocos nucifera L.), cotton, maize, mango (Mangifera indica L.), melon, papaya (Carica papaya L.), pineapple (Ananas comosus (L.) Merril), sorghum and watermelon. These areas were located in the semi-arid region of the $\mathrm{RN}$ and $\mathrm{CE}$ states. Five areas from each crop and tropical dry forest were sampled, all of them were also georeferenced. In respect to areas cultivated with melon, 5 soil samples were collected according to their planting history: 1,5 and 10 years (Table 1). Each sample was represented by 10 sub-samples, collected in zigzag at depth of 0 to $20 \mathrm{~cm}$, which is the zone of highest ascospore concentration of $M$. cannonballus (Mertely et al., 1993). In these producing areas, data regarding their collapse history caused by $M$. cannonballus were also gathered.

\section{Processing of soil samples}

After soil collection, the samples were shade dried and sieved in a $2 \mathrm{~mm}$ mesh for residue removal. Six replicates of $20 \mathrm{~g}$ were obtained from each soil sample, constituting the replicates, from which the ascospores of $M$. cannonballus were extracted by the sucrose flotation method, according to Beltrán et al. (2005) and adjusted by Sales Júnior $e t$ al. (2006).

Initially, the soil samples were sieved in a $250 \mu \mathrm{m}$ mesh in order that larger particles were eliminated. After that, a $20 \mathrm{~g}$ sample of each sieved soil was placed in $500 \mathrm{ml}$ of water, stirred for $5 \mathrm{~min}$ and then passed through 75 and 30 $\mu \mathrm{m}$ mesh sieves.

The particles retained in the $30 \mu \mathrm{m}$ mesh sieve were washed using running water and centrifuged at $900 \mathrm{~g}$ for 4 min. The supernatant was then discarded, and the particles were dissolved in $40 \mathrm{~mL}$ of $50 \%$ sucrose solution and centrifuged at $900 \mathrm{~g}$ twice for $2 \mathrm{~min}$. The supernatant obtained from the last step went through a $30 \mu \mathrm{m}$ mesh sieve one more time, and the retained particles were distributed in Petri dishes, where the counting of ascospores were proceeded morphologically defined by (Mertely et al., 1993) on a stereoscopic microscope at 40x.

\section{Data analysis}

The mean of the data yielded from this study for levels of ascospores $\mathrm{g}^{-1}$ soil belonging to the treatments did not meet the assumptions of the variance analysis (normality of error distribution and homogeneity of variances). The obtained data were verified by the Kolmogorov-Smirnov, Kuiper and Lilliefors statistical normality tests $(\mathrm{P}>0.05)$, which were then transformed by the equation $\mathrm{X}=\sqrt{X}$ and submitted to analysis of variance. The means were compared by the Scott-Knott test $(\mathrm{P}=0.05)$ and all the statistical analyzes were carried out with the assistance of the program Assistat Software Version 7.7 (Silva and Azevedo, 2016). 


\section{Results and Discussion}

Ascospores of $M$. cannonballus were detected in all sampled soils, with values varying from 0.74 to 1.47 ascospores $\mathrm{g}^{-1}$ soil, with significant difference $(\mathrm{P}<0.05)$ among the areas (Table 1). The highest density of ascospores was found in the soils cultivated with papaya (1.47 ascospores $\mathrm{g}^{-1}$ soil), differing statistically from the other crops, such as tropical dry forest, which can be considered as control because it was not anthropized nor cultivated. Ascospores of Monosporascus have been found in soils of semiarid regions around the world such as Arizona (U.S.A.), India, Iran, Libya and Pakistan (Reuveni and Krikun,1983), due to their temperature that is great for the pathogen, which is considered to be a thermophilic fungus, providing it greater competitive and adaptive capacity to soils of dry and semi-arid areas (Medeiros et al., 2006).

In cultivated cucurbitaceous areas, the highest densities of ascospores in soil were observed in areas with watermelon (1.27 ascospores $\left.\mathrm{g}^{-1}\right)$ and melon cultivated by 10 years $(1.08$ ascospores $\left.\mathrm{g}^{-1}\right)$, differing significantly $(\mathrm{P}<0.05)$ from areas with one and five years of melon cultivation, whose densities were 0.76 and 0.74 , respectively. These results were already expected, because $M$. cannonballus colonizes roots of cucurbitaceae such as the crops mentioned ahead (Medeiros et al., 2008a), participating in the pathogen-host relationship in which their roots serve as source of inoculum for the pathogen to settle, colonize for a better reproduction and/or its survival by the formation of ascospores.

A previous study conducted by Andrade et al. (2005) has shown that $M$. cannonballus is widely disseminated in areas cultivated with melon in the states of RN and CE. Subsequently, Medeiros et al. (2006), analyzing different soils of cucurbitaceous and Caatinga biome producing areas, has reported the presence of $M$. cannonballus ascospores, concluding that it was not introduced in Brazil by propagating material, but it was already a natural inhabitant of the soil microbiota in this region.
Prospecting studies in melon production fields in the State of RN in different crops and sampling areas performed by Medeiros et al. (2008b) have found similar densities of ascospores in areas cultivated with cotton ( 0.99 ascospores $\left.\mathrm{g}^{-1}\right)$, coconut $\left(1.19\right.$ ascospores $\left.\mathrm{g}^{-1}\right)$ and Caatinga biome (0.3 ascospores $\left.\mathrm{g}^{-1}\right)$. On the other hand, this same authors have also detected levels of ascospores in soil much higher than those detected in this study for crops such as mango (2.0 ascospores $\mathrm{g}^{-1}$ ), watermelon (2.6 ascospores $\mathrm{g}^{-1}$ ) and melon $\left(8.09\right.$ ascospores $\left.\mathrm{g}^{-1}\right)$. Possibly, this difference may have been due to the type of management applied by the producer, who often incorporate cultural remains of melon and watermelon or apply the thermal blanket technique. The first action favors the multiplication of $M$. cannonballus inoculum, which was already proven by Stanghellini et al. (2004), and the second results in soil heating which eventually benefit thermophilic fungi (Medeiros et al., 2008a).

There was no significant difference between the density of $M$. cannonballus ascospores in soils cultivated with coconut (0.97 ascospores $\left.\mathrm{g}^{-1}\right)$, cotton ( 0.74 ascospores $\left.\mathrm{g}^{-1}\right)$, mango ( 0.99 ascospores $\left.\mathrm{g}^{-1}\right)$, melon with 5 and 10 years of cultivation ( 0.74 and 0.76 ascospores $\mathrm{g}^{-1}$, respectively), pineapple $\left(0.97\right.$ ascospores $\left.\mathrm{g}^{-1}\right)$ and tropical dry forest $(0.97$ ascospores $\mathrm{g}^{-1}$ ) (Table 1). These results corroborate with those obtained by Stanghellini et al. (1996) when they verified this similarity in the population density of this fungus in melon fields with and without history of disease, as well as in native desert soils. However, the amount of ascospores in the soil cannot be the only factor to be taken into account when predicting that a certain area will be affected by the disease. For instance, the percentage of germinating ascospores may be different according to several aspects such as virulence, plant susceptibility and soil conditions. Besides, previous studies conducted by Stanghellini et al. (2000) have shown that the actinomycetes are involved, directly or indirectly, in the induction of germination of $M$. cannonballus ascospores in field soil in

Table 1. Density of ascospores of Monosporascus cannonballus in soils from tropical dry forest areas and cultivated fields with different crops from the Brazilian semiarid region

\begin{tabular}{|c|c|c|c|}
\hline Crop & Municipality-State ${ }^{1}$ & $\begin{array}{c}\text { MRRVD } \\
\text { history }^{2}\end{array}$ & $\begin{array}{c}\text { Density of ascospores } \\
\left(\mathrm{g}^{-1} \text { soil }\right)\end{array}$ \\
\hline Cotton & Assú-RN & - & $0.74 \mathrm{c}$ \\
\hline Melon ( 5 years) & Icapui-CE & + & $0.74 \mathrm{c}$ \\
\hline Melon $(1 \text { year })^{4}$ & Icapui-CE & - & $0.76 \mathrm{c}$ \\
\hline Coconut & Mossoró-RN & - & $0.81 \mathrm{c}$ \\
\hline Pineapple & Icapui-CE & - & $0.97 \mathrm{c}$ \\
\hline Tropical dry forest & Icapui-CE/Mossoró-RN & - & $0.97 \mathrm{c}$ \\
\hline Mango & Baraúna-RN/Icapui-CE & - & $0.99 \mathrm{c}$ \\
\hline Melon (10 years) & Icapui-CE & + & $1.08 \mathrm{~b}$ \\
\hline Sorghum & Icapui-CE / Mossoró-RN & + & $1.08 \mathrm{~b}$ \\
\hline Maize & Icapui-CE/Mossoró-RN & - & $1.12 \mathrm{~b}$ \\
\hline Watermelon & Baraúna-RN/Icapui-CE & - & $1.21 \mathrm{~b}$ \\
\hline Papaya & Baraúna-RN/Mossoró-RN & - & $1.47 \mathrm{a}$ \\
\hline CV $(\%)$ & & & 20.54 \\
\hline
\end{tabular}


the presence of exudates originated from cantaloupe melon roots.

Recent studies have reported that the germination of $M$. cannonballus ascospores is straightly mediated by Olpidium bornovanus (Sahtiy.) Karling, an obligate root pathogen, zoosporic (Stanghellini and Misaghi, 2011; Stanghellini et al., 2014; Aleandri et al., 2017), and vector of the Melon necrotic spot virus - MNSV, also associated with the MRRVD in melon (Herrera-Vásquez et al., 2010).

Correspondingly, it is important to emphasize that melon and watermelon areas, especially those with high incidence of MRRVD and low productivity, are utilized for cultivation of other crops in order to reduce the fungal inoculum and maintain the activity in these fields. It is also important to note that migration to new areas is a common practice for farmers when productivity is compromised due to root diseases.

The areas that were cultivated with melon or watermelon are generally used for the cultivation of perennial and semi-perennial crops, such as mango and papaya, respectively, as well as sorghum and maize (Medeiros et al., 2006). Nevertheless, it is noticed that even with the use of non-host crops of $M$. cannonballus, there is persistence of its inoculum. This can be the result of the multiplication of their ascospores as a way for survival in the melon and watermelon roots that were previously incorporated into the soil.

The destruction and /or removal of infected cultural remains is a management strategy widely used by farmers to reduce the inoculum of phytopathogenic fungi (Baird et al., 2003). However, studies carried out by Stanghellini et al. (2004) have shown that the practice of applying herbicides in volunteer plants and destruction of cultural remains is not always that much efficient for the management of $M$. cannonballus. The results provide confirmatory evidence on how difficult is its control.

Despite the low density of ascospores found in these areas, this event is quite concerning because $M$. cannonballus is one of the most aggressive fungi associated with melon roots (Beltrán et al., 2005). Additionally, its initial inoculum is incorporated into the soil, multiply at the end of each crop cycle, and may remain in the soil for several years (Beltrán et al., 2005).

The higher density of ascospores in areas with 10 years of melon cultivation and the ones cultivated with watermelon can be explained by the monoculture of the melon and the use of mulch that generates a higher soil temperature, selecting the most thermotolerant fungi such as M. cannonballus (Medeiros et al., 2008a).

High densities of ascospores have been reported in many melons producing areas in Brazil (Medeiros et al., 2008b) and abroad (Mertely et al., 1993; Beltrán et al., 2008) in soils with temperature between 25 and $30{ }^{\circ} \mathrm{C}$ (Waugh et al., 2003), without moisture saturation (Beltrán et al., 2005).

The increase in the density of $M$. cannonballus inoculum does not significantly influence the intensity of the disease (Beltrán et al., 2008), but low values of density (0.1 colonyforming units $\mathrm{g}^{-1}$ soil) produce elevate severities indicating the high viability and infectivity of fungus propagules in the soil, as well as reinforce its great destructive potential (Andrade et al., 2005).
It is important to note that the detection of $M$. cannonballus ascospores may be relevant to predict the future risks of disease in the field (Beltrán et al., 2005). In Brazil, there is still no parameter that indicates a risk threshold for the number of ascospores necessary to cause disease.

Melon fields are seen as problematics when they present minimum of 2.0 ascospores $\mathrm{g}^{-1}$ soil (Waugh et al., 2003). If this value was taken into account, this soil would be considered with low risk threshold, once it shows levels somewhat under the average. However, little is known about which factor is responsible for the increase in infectivity and virulence of ascospores.

As $M$. cannonballus inoculum already existed when the melon was introduced into tropical dry forest areas and the disease incidence levels remained alarming until 2002, the significant increase in disease could be associated with changes in production technology which called for intensive exploitation, such as monoculture, increased planting density, high-frequency drip irrigation and the use of mulch. These changes may be creating favorable conditions for the increase in the infectivity of $M$. cannonballus ascospores and the development of the disease (Cohen et al., 2012).

Areas with papaya cultivation exhibited the highest ascospores densities of $M$. cannonballus. Up to date, there is no study to prove that this crop is considered host of the fungus. However, many factors may be associated in the ecology of this pathogen in soils with papaya, such as the history of the areas, incorporation of cultural remains from previous crops and the use of techniques that may be increasing soil temperature, therefore, favoring the development and selection of thermophilic fungi.

Based on what was shown, further research is required to analyze whether papaya can become a host to $M$. cannonballus in Brazilian dry tropical areas as well as which edafo-climatic factors stimulate the increase of the population density of this fungus in crop succession.

\section{Conclusions}

There is no direct relationship between $M$. cannonballus population density in the soil and the susceptibility of the host being cultivated in the soil at the time of sampling. Residual populations of $M$. cannonballus present in the soil prior to planting of the new crop in the areas seems to be determinant for the population density detected at the time of sampling.

\section{Acknowledgements}

The authors Sami Jorge Michereff, Rui Sales Júnior and Erika Valente de Medeiros are CNPq productivity research fellows. The authors thank the CNPq for the financial support given for the accomplishment of the present study.

\section{References}

Aleandri MP, Martignoni D, Reda R, Alfaro-Fernández A, Font MI, Armengol J, Chilosi G (2017). Involvement of Olpidium bornovanus and $O$. virulentus in the occurrence of melon root rot and vine decline caused by Monosporascus cannonballus in Central Italy. Journal of Plant Pathology 99:169-176. 
266

Alves AR, Ferreira RLC, Silva JAA, Dubeux Júnior JCB, Osajima JA, Holanda AC (2017). Conteúdo de nutrients na biomassa e eficiência nutricional em espécies da Caatinga [Content of nutrients in the biomass and nutritional efficiency in species of 'Caatinga' biome]. Ciência Florestal 27:377-390.

Al-Mawaali QS, Al-Sadi AM, Al-Said FA, Deadman ML (2013). Etiology, development and reaction of muskmelon to vine decline under arid conditions of Oman. Phytopathologia Mediterranea 52:457-465.

Alvares CA, Stape JL, Sentelhas PC, Gonçalves JLM, Sparovek G (2014). Köppen's climate classification map for Brazil. Meteorologische Zeitschrift 22:711-728.

AndradeEM(2017). A floresta tropical seca, caatinga: Ascertezas e incertezas das águas [Caatinga, the tropical dry forest: the certainties and uncertainties of water]. Tordesillas Revista de Investigación Multidisciplinar 12:11-20.

Andrade GT, MichereffSJ, Biondi CM, Nascimento CWA, Sales Júnior R (2005). Frequência de fungos associados ao colapso do meloeiro e relação com características fisicas, químicas e microbiológicas dos solos [Frequency of fungi associated with melon colapse and its relationship with physical, chemical and microbiological characteristics of soils]. Summa Phytopathologica 31:327-333.

ANUÁRIO (2017). Anuário Brasileiro da Fruticultura [Brazilian Fruit Yearbook]. Gazeta Press, Brasil.

Baird RE, Watson CE, Scruggs M (2003). Relative longevity of Macrophomina phaseolina and associated mycobiota on residual soybean roots in soil. Plant Disease 87:563-566.

Beltrán R, Vincent A, García-Jiménez J, Armengol J (2008). Comparative epidemiology of Monosporascus root rot and vine decline in muskmelon, watermelon, and grafted watermelon crops. Plant Disease 92:158-163.

Beltrán R, Vincent A, Sales Júnior R, García-Jiménez J, Armengol J (2005). Population dynamics of Monosporascus cannonballus ascospores in marsh soils in eastern Spain. European Journal of Plant Pathology 113:357-365.

Cohen R, Pivonia S, Crosby KM, Martyn RD (2012). Advances in the biology and management of monosporascus vine decline and wilt of melons and other cucurbits. Horticultural Review 39:77-120.

Herrera-VásquezJA, Córdoba-Sellés MC, Cebrián MC, RosselóJA, AlfaroFernández A, Jordá C (2010). Genetic diversity of Melon necrotic spot virus and Olpidium isolates from different origins. Plant Pathology 59:240-251.

IBGE (2016). Instituto Brasileiro de Geografia e Estatística - Produção Agrícola Municipal [Brazilian Institute of Geography and Statistics Municipal Agricultural Production]. Brasil. Retrieved 2018 April 05 from https://sidra.ibge.gov.br/tabela/1612.

Markakis EA, Trantas EA, Lagogianni CS, Mpalantinaki E, Pagoulatou M, Ververidis F, Goumas DE (2018). First report of root rot and vine decline of melon caused by Monosporascus cannonballus in Greece. Plant Disease 102:1036.

Martyn RD, Miller ME (1996). Monosporascus root rot and vine decline: an emerging disease of melons worldwide. Plant Disease 80:716-725.

Medeiros EV, Sales Júnior R, Michereff SJ, Barbosa MR (2006). Quantificação de ascósporos de Monosporascus cannonballus em solos não cultivados de Caatinga e em áreas de cultivo de melão do Rio
Grande do Norte e Ceará [Quantification of Monosporascus cannonballus ascospores in non-cultivated soils of Caatinga and melon producing fields in Rio Grande do Norte and Ceará States]. Fitopatologia Brasileira31:500-504.

Medeiros EV, Serafim ECS, Granjeiro LC, Sobrinho JE, Negreiros MZ, Sales Júnior R (2008a). Influência do agrotêxtil sobre a densidade populacional de Monosporascus cannonballus em solos cultivados com melancia (Citrullus lanatus) [Influence of the row cover on the population density of Monosporascus cannonballus in soil cultivated with watermelon (Citrullus lanatus)]. Ciênciae Agrotecnologia 32:797-803.

Medeiros EV, Silva KJP, Oliveira L, Ferreira HA, Sales Júnior R (2008b). Monosporascus cannonballus density in soils cultivated with different crops in Rio Grande do Norte State, Brazil. Revista Brasileira de Ciências Agrárias 3:1-5.

Mertely JC, Martyn RD, Miller ME, Bruton BD (1993). Quantification of Monosporascus cannonballus ascospores in three commercial muskmelon fields in south Texas. Plant Disease 77:766-771.

Radewald KC, Ferrin DM, Stanghellini ME (2004). Sanitation practices that inhibit reproduction of Monosporascus cannonballus in melon roots left in the field after crop termination. Plant Pathology 53:660-668.

Reuveni R, Krikun J (1983). Occurrence of Monosporascus eutypoides under arid conditions in Israel. Transactions of the British Mycological Society 80:354-356.

Sales Júnior R, Balbino DAD, Negreiros AMP, Barboza HDS, de Medeiros EV, Armengol J (2018). Cotton, cowpea and sesame are alternative crops to cucurbits in soils naturally infested with Monosporascus cannonballus. Journal of Phytopathology 1:1-7.

Sales Júnior R, Beltrán R, Michereff SJ, Armengol J, García-Jiménez J, Medeiros, EV (2006). Análisis de distintos tipos de azúcares en el método de extracción de ascosporas de Monosporascus cannonballus en suelo [Analysis of different types of sugar in the extraction method of ascospores of Monosporascus cannonballus in soil]. Fitopatologia Brasileira31:185-187.

Sales Júnior R, Beltrán R, Vicent A, Armengol J, García-Jiménez J, Medeiros EV (2007). Controle biológico de Monosporascus cannonballus com Chaetomium [Biological control of Monosporascus cannonballus by Chaetomium]. Fitopatologia Brasileira 32:70-74.

Sales Júnior R, Santana CVS, Nogueira DRS, Silva KJP, Guimarães IM, Michereff SJ, ... Armengol J (2010). First report of Monosporascus cannonballus on watermelon in Brazil. Plant Disease 94:278.

Sales Júnior R, Nascimento IJB, Freitas LS, Beltrán R, Armengol J, Vicent A, García-Jiménez J (2004). First report of Monosporascus cannonballus on melon in Brazil. Plant Disease 88:84.

Sales Júnior R, Oliveira OF, Medeiros EV, Guimarães IM, Correia KC, Michereff SJ (2012). Ervas daninhas como hospedeiras alternativas de patógenos causadores do colapso do meloeiro [Weeds as alternative hosts of melon colapse pathogens]. Revista Ciência Agronômica 43:195-198.

Senhor R, Souza PA, Andrade Neto RC, Pinto AC, Soares SRF (2009). Colapso do meloeiro associado a Monosporascus cannonballus [Collapse of melon plant Monosporascus cannonballus]. Revista Verde de Agroecologiae DesenvolvimentoSustentável 4:06-14. 
Silva FAS, Azevedo CAV (2016). The Assistat Software Version 7.7 and its use in the analysis of experimental data. African Journal of Agricultural Research 11:3733-3740.

Stanghellini ME, Kim DH, Waugh MM (2000). Microbe-mediated germination of ascospores of Monosporascus cannonballus. Phytopathology 90:243-247.

Stanghellini ME, Waugh MM, Radewald KC, Kim DH, Ferrin DM, Turini T (2004). Crop residues destruction strategies that enhance rather than inhibit reproduction of Monosporascus cannonballus. Plant Pathology 53:50-53.

Stanghellini ME, Mohammadi M, AdaskavegJE (2014).Effect of soil matric water potentials on germination of ascospores of Monosporascus cannonballus and colonization of melon roots by zoospores of Olpidium bornovanus. European Journal of Plant Pathology 139:393-398.
Stanghellini ME, Kim DH, Rasmussen SL (1996). Ascospores of Monosporascus cannonballus: germination and distribution in cultivated and desert soils in Arizona. Phytopathology 86: 509-514.

Stanghellini ME, Misaghi IJ (2011). Olpidium bornovanus-mediated germination of ascospores of Monosporascus cannonballus: a host-specific rhizosphere interaction. Phytopathology 101:794796.

Waugh MM, Kim DH, Ferrin DM, Stanghellini ME (2003). Reproductive potential of Monosporascus cannonballus. Plant Disease 87:45-50.

Yan LY, Zang QY, Huang YP, Wang YH (2016). First report of root rot and vine decline of melon caused by Monosporascus cannonballus in Eastern Mainland China. Plant Disease 100:651. 